 \\ JDSS Journal of Development and Social Sciences WWW.Jdss.org.,pk \\ RESEARCH PAPER
}

\section{US Taliban Doha Accord: A Compromise}

\author{
${ }^{1}$ Muhammad Muzaffar ${ }^{2}$ Syed Tanveer Ali Shah* ${ }^{3}$ Sidra Karamat
}

1. Assistant Professor, Department of Political Science, GCWU, Sialkot, Punjab, Pakistan

2. Visiting Lecturer, Department of International Relations, Karakorum International University Gilgit, Pakistan

3. Visiting Lecturer, Department of Political Science and International Relations, GCWU Faisalabad, Punjab, Pakistan

\begin{tabular}{|c|c|}
\hline $\mathrm{ni}$ & \\
\hline & \multirow{11}{*}{$\begin{array}{l}\text { This paper attempts to find out that the US peace agreement with the } \\
\text { Taliban is a promising step, but is rife with ambiguities because the } \\
\text { hasty peace deal reached in Doha on February } 29 \text { has undermined the } \\
\text { Afghan government and avenged the US-Taliban's nefarious zero-sum } \\
\text { game. It can change all that goes forward. However, it marks a } \\
\text { significant breakthrough in the two adversaries nearly two-decade } \\
\text { long conflict and a peaceful terrorism-free Afghanistan is the desire of } \\
\text { everyone in the region. But the current environment in Afghanistan, in } \\
\text { which the agreement signed, raises some questions in the minds of all } \\
\text { strategists .Is it a compromise, or a doomed deal? All the stakeholders } \\
\text { expressed hopes of peace returning to Afghanistan, but various } \\
\text { dignitaries could not hide the apprehensions about the longevity of the } \\
\text { deal as well as prospects for peace in the statements }\end{array}$} \\
\hline & \\
\hline & \\
\hline & \\
\hline & \\
\hline & \\
\hline & \\
\hline & \\
\hline & \\
\hline & \\
\hline & \\
\hline
\end{tabular}

\section{Introduction}

According to the structural realism theory, "When States believe that actions are legal, they will use force outside their territory, and when they believe that current actions are illegal, they will stop using force". Nearly 19 years later, for the first time, the United States viewed the non-state actor as a legitimate stakeholder, previously termed terrorists. Such stakeholders will now have the power to rule Afghanistan, and will decide Kabul's future. The United States signed a peace treaty with the Taliban at Doha, Qatar, on 29 February 2020. "The agreement, officially called "Agreement to Bring Peace to Afghanistan" is written in three languages; Dari, Pashtu, and English. It has two parts; the Taliban accept that "Afghan soil won't be used against U.S. security and its allies" and the U.S. agrees with the removal of all foreign forces from Afghanistan. The accord was reached by a 7-day "reduction in violence", a term used instead of a "ceasefire", a term opposed by the Taliban, partly because a "ceasefire" suggested an end to hostilities that the Taliban were not willing to commit"(Allen, 2020, March 5).

Specifically, the agreement specifies that all military personnel, including military and "non-diplomatic civilian personnel, private security contractors, trainers, advisors, and 
support staff," must be withdrawn by the United States and the Coalition forces within fourteen months of the agreement's signature. "The agreement also states that the U.S. forces in Afghanistan will be reduced to 8,600 within the first 135 days of the agreement being signed, and that the U.S. and the Coalition must withdraw all troops from five military bases, even within the first 135 days of the agreement being signed"(Allen, March 5, 2020).Furthermore, according to the agreement, the United States and the Coalition forces must vacate all military bases and withdraw the remaining military personnel within nine and a half months after the agreement has been signed, which is by the middle of November 2020.This total decrease in U.S. and Coalition forces is conditioned on the Taliban living up to their side of the deal by not allowing "Afghan soil to be used against U.S. security and its allies".

The agreement also states that on March 10, 2020, a date that has already passed, the Taliban and the Afghan Government will begin a "dialog and negotiation". The particular aspects of this "discourse and negotiation" are not specified, but they are believed to include at least the Taliban's position in a future Afghan government, the position of Islamic law in the Afghan constitution, the security and rights of women and other minorities, and eventually, the country's leadership. The agreement states that as a precursor to intra-Afghan negotiations, the United States agrees to "work with all relevant sides" to release combat and political prisoners. The agreement stated that 5000 Taliban prisoners would be released by the Afghan government by March 10, 2020 and that 1000 Afghan prisoners would be released by the Taliban. The release of prisoners is described as a "builder of confidence" to start dialogue between the Taliban and the Afghan Government. Eventually, the agreement specifies that the United States must pursue diplomatic negotiations with the United Nations to remove Taliban leaders from the "sanctions list"(Ramachandran, 2020).

The deal seeks to wind down nearly twenty years of war in Afghanistan, following the rise of the Taliban to power in the 1990s and the September 11, 2001 terrorist attacks in the United States. Negotiations excluded the Afghan government, though aspects of the peace deal - in particular the bilateral prisoner swap - required involvement from Kabul. Afghan President Ashraf Ghani initially refused the U.S. and Taliban deal to exchange prisoners, saying that "it's not up to the U.S. to say, they're just a facilitator."Although the Afghan Government eventually approved the release of 1,500 Taliban prisoners (of the 5,000 required by the deal), the initial rejection of this clause by President Ghani and the overall resumption of violence raise concerns that the peace deal may indeed be short-lived. Whether the agreement actually aimed to direct Afghanistan towards a democratic and stable future remains uncertain, or merely to give the administration of US President Donald J. Trump a politically palatable escape from the longest armed conflict in the United States (Ramachandran, 2020).

The following questions must be answered by both sides if the peace process is to be saved and Afghanistan eventually steered away from the spiraling chasm of perpetual war.

- Who represents the Afghan people? Are we referring to an Afghanistan that was once ruled by the Taliban or a new Afghanistan that has been transformed in so many ways? 
- What exactly does a political settlement between Kabul and the Taliban look like?

- Will Taliban be granted an autonomous Afghan region to rule with a separate set of political structures that govern their relationship with the Kabul political centre?

- Will US security forces and NATO be able to fully disengage? If not, what does it feel like to be partially evacuated?

- Can the Taliban be trusted to ensure that al-Qaeda and Islamic State do not operate in Afghanistan, especially given the low level of US security?

- How can a Kabul-Taliban political settlement affect the Taliban's complex relationship with Pakistan?

- How will Kabul be extending and increasing its authority across Afghanistan?

- Does the Intra-Afghan Dialogue involve the intricate illicit patronage networks in Afghanistan?

- What about refugees from Afghanistan who live in Iran, Pakistan and elsewhere?

\section{Problems: Where Was Kabul?}

The agreement requires a variety of assumptions that are troublesome. As one thing, the Afghan government was neither part of the talks nor a signatory to the final agreement. While Ambassador Zalmay Khaililzad of the United States made an effort to keep the Afghan President Ashraf Ghani updated and on board but the Afghan government became increasingly worried and resentful as the talks progressed that they were excluded in discussions regarding their own country's future. The fact that the Afghan government or its members were not permitted to participate in the talks came at the behest of the Taliban, who claimed that the new government in Afghanistan was not a legitimate government but a US puppet. If that is valid or not can be argued but on this topic the Taliban prevailed (Ahmadzai, 2020).

Since the agreement includes terminology regarding various steps that the Afghan Government will take, its non-participation in the talks has created an obstacle to future negotiations and has frustrated Afghan President Ashraf Ghani and other Afghan officials. "Specifically, in the agreement, the United States agreed that the Afghan Government will release up to 5,000 Taliban prisoners as a "trust builder" between the Taliban and the Kabul government by March 10, 2020, and the Taliban will release 1,000 prisoners that they keep at the same time"(Ahmadzai, 2020). Nevertheless, the Afghan Government retains the prisoners, not the United States. Since the Afghan government has not been a part of the agreement, it feels no obligation to release Taliban prisoners whom they consider terrorists. As a result, the next step in the Taliban-afghan government negotiations is on hold.Afghan President Ghani initially stated that he would not release any Taliban prisoners, but by March 15, 2020, several days after the start of peace talks between the Afghan government and the Taliban, he declared that he would free 1,500 Taliban prisoners. He also insisted that any Taliban inmate released would have to sign an agreement promising not to return to the war.This settlement has not been accepted by the Taliban to date and, as a result, talks vital to the next step in negotiations between the Taliban and the Afghan Government has yet to begin(Ramachandran, 2020). 


\section{Afghan Presidential Elections}

Afghan's last presidential election was held on September 28, after being postponed for several years. The results were not announced until February 18, 2020, almost five months after the elections, because of various delays and demonstrations by different candidates."The election commission reported that when the results were finally announced, President Ghani won 50.64 percent of the vote, followed by Abdullah Abdullah who won 39.5 percent of the national vote"(Commission, 2020). The Afghan constitution specified that the candidate who wins more than 50 percent of the vote in a multiple candidate election is the winner. Instead of answering the Afghan leadership issue, however, the election results created more confusion. There have been several electoral violations, including abuse at many polling stations, the use of new biometric voting systems, and outright voter fraud. "As a result, of the 9.6 registered voters, only about 1.8 million voted and nearly 300,000 votes were disputed and many were disallowed"(Commission, 2020). As a consequence, Abdullah Abdullah and several other candidates cried foul, refusing to recognize Ashraf Ghani as the legitimate winner.As a result of this disputed election, both Abdullah Abdullah and Ashraf Ghani declared themselves winners and, after a failed effort by American diplomat Ambassador Zalmay Khalizad to overcome the impasse, as Secretary of State John Kerry did in 2014, both candidates declared themselves winners and had simultaneous swearing in ceremonies at their neighboring palaces. "With no clear winner in Kabul, the Taliban have no apparent party to bargain with. Consequently, the intra-Afghan talks, crucial for the next step in bringing peace to Afghanistan, cannot be conducted"(Datta, 2019, September 16).

\section{The Taliban}

Although it is not clear who is speaking for the Afghan Government, who is speaking for the Taliban is also not clear. The Taliban is not a single umbrella group, but is comprised of different factions and forces in Afghanistan, many of whom with contradictory views about the war and now about the peace settlement. The members of the Taliban who signed the peace agreement are from the Taliban leadership group known as the Quetta Shura. This group operates outside of Pakistan and is largely political and economic. "The Quetta Shura controls the highly profitable trade in opium and heroin that supports Afghanistan's Taliban military operations. Senior Taliban, including Haibutullah Akhundzada, Mohammed Yaqub, Mohammed Omar and Abdul Ghani Baradar, head the Quetta Shura"(Thomas, May 1, 2020). Although these leaders exert tremendous power within the Taliban, they have little or no military experience, and the commanders in the field are therefore openly contemptuous. Generally, those commanders are younger than the Quetta Shura, mostly in their 20s and 30s.Many are working in remote and hostile areas of Afghanistan with little relation to or guidance from Quetta's Taliban leadership. After all, the Taliban's true strength was in the military performance of these local commanders in Afghanistan (Thomas, 2020, May 1).

The Taliban now controls nearly 50 percent of the Afghan countryside, thanks to the work of these regional commanders. They are the backbone of the Taliban and many have differing views on what a peace deal would be with the United States. The friction within the Taliban leadership came to a head on February 29, 2020, when the political leadership called for a reduction in violence as a prelude to the agreement signing. Instead 
of following the decline in aggression many commanders continued to attack and kept fighting. While these commanders may applaud the withdrawal of U.S. forces from Afghanistan, they are cautious about negotiating with a Kabul government that they distrust.

\section{Intra-Afghan Talks and Obstacles}

The U.S.-Taliban agreement allows for an end to the U.S. military operation in Afghanistan, but it does not constitute a substantive peace agreement that most analysts can only determine by negotiating a diplomatic settlement between the Taliban and the Afghan government. The agreement states that, on March 10, 2020, the Taliban will "begin intra-Afghan negotiations," but no talks have been scheduled or held so far. The extent to which the U.S. withdrawal is contingent on or otherwise related to the Taliban holding talks with Kabul or the outcome of those talks is unclear. Deputy U.S. negotiator Molly Phee said, "We are not going to prejudge the outcome of intra-Afghan negotiations, but we are willing to support whatever consensus the Afghans can reach on their future political and governing arrangements"(Gallagher, February 20,2020).Which sort of political settlement could satisfy both Kabul and the Taliban remains uncertain to the degree that the latter abandons their armed struggle? Afghan President Ghani has vowed that his government would not consider any arrangement that would limit the rights of Afghans, and has cautioned that any deal to remove U.S. troops that did not include Kabul's involvement could lead to "catastrophe," referring to the civil unrest of the 1990s following the collapse of the Soviet-backed government that led to the rise of the Taliban (Rogin, 2020, April. 18).

Afghans opposed the Taliban doubt the trustworthiness of the group and express concern that, in the absence of U.S. military pressure, the group would have little motivation to comply with the terms of an agreement, the most important element of which will probably be to reach a substantive political settlement with the government of Afghanistan. The Taliban have provided conflicting signals, and generally do not explain in depth their vision for Afghan governance post-settlement beyond referring to it as a topic for intra-Afghan negotiations. Many Afghans, especially women, who recall Taliban rule and oppose the policies and beliefs of the group remain wary. Nonetheless, a survey carried out in December 2019 indicated that a "valuable majority" of Afghans are both aware of $(77 \%)$ and strongly or somewhat support (89\%) attempts to pursue a peace deal with the Taliban while opposing the organization itself. One nascent measure of progress has been the establishment of a 21-member negotiating team by the Afghan Government in the months after the U.S.-Taliban deal, declared on March 26, 2020. The group, which includes five women, has been endorsed by the US, and perhaps more significantly by figures from across the Afghan political spectrum, including Abdullah and other Ghani opponents. The Taliban, nonetheless, rejected that team and maintained their refusal to negotiate with Kabul. There are also a number of issues outlined below which complicate and undermine potential talks (Rogin, 2020, April. 18).

\section{Prisoner Exchange}

A scheduled prisoner exchange has emerged as the most significant barrier to intra-Afghan talks viewed as crucial to resolve the Afghanistan war. "Some experts point out that the U.S. [used] different language in separate documents agreed with the Taliban and the government of Afghanistan. In particular, the U.S.-Taliban agreement notes that up 
to 5,000 Taliban prisoners and 1,000 Afghan forces held by the Taliban will be released by March 10, 2020"(Gallagher, February 20, 2020)while the U.S.-Afghan Government Joint Declaration notes that the Afghan Government will "participate in a U.S.-facilitated dialogue" with the Taliban on "the possibility of releasing large numbers of prisoners on both sides". On 11 March 2020, President Ghani signed a decree that would release 1,500 prisoners within 15 days as long as they provide written assurances that they will remain off the battlefield, with further releases of 500 prisoners every two weeks as long as the Taliban engage in talks and reduce violence. A Taliban spokesman dismissed any conditions-based release of prisoners as "against the peace deal we signed," and insisted on freeing 5,000 prisoners before any intra-Afghan negotiations. Despite the Taliban not obviously meeting the conditions of the Afghan government, some limited releases have taken place: as of May 2020, several hundred Taliban prisoners have been released by the Afghan government, and several dozen Afghan personnel have been released by the Taliban in turn (Ramachandran, 2020).

\section{Renewed Violence}

The resumption and escalation of regional violence is another possible obstacle to intra-Afghan talks. While the Taliban refrained from targeting Afghan forces during the preceding agreement's weeks-long reduction in violence, they resumed operations immediately after the deal and violence has now reached levels comparable to previous months.US military officials have interpreted Taliban attacks differently. In a March 2 media conference, Secretary of Defense Esper said that "our expectation is that the reduction in violence will continue it will taper off until we get intra-Afghan negotiations". The reason for that expectation is not clear; there is no provision in the U.S.-Taliban agreement to promise the Taliban to continue to refrain from attacking the Afghan forces. CENTCOM Commander-General Frank McKenzie said on March 10 that the U.S.-Taliban deal "is higher than we think it is compatible with a concept to actually carry out". U.S. officials have since maintained that Taliban violence is "unacceptably high," while violence has increased: an average of 25 to 40 Afghan security personnel were killed each day in mid-April according to Afghan officials.

\section{Intricate illicit patronage networks in Afghanistan}

The peace deal completely ignores the undergirded conflict, corruption, instability and international criminal patronage of illegal economies and networks in Afghanistan. Optimizing the illegal economies to the turmoil of war and lacking centralized political authority make them one of the most damaging challenges to stability and the intra-Afghan dialogue. A stronger Kabul will certainly combat powerful criminal patronage networks, trading in illicit goods such as talc, opium, coal, methamphetamine, timber and human trafficking. A strong stake in Afghanistan remains unstable and malleable to their interests, the actors who benefit from these trades. In addition, the Afghan government cannot realistically hope to consolidate its authority across Afghanistan and establish a powersharing arrangement with the Taliban if the peace talks lack illicit structures interwoven with the war climate. "A negotiated settlement will be at considerable risk without adequate attention being paid to criminal networks, their regional and foreign tangles, and a thorough understanding of their interests and motives"(Larson, 2020). 
The enabling corruption and abuse of the security sector by the US government in the Afghan government leaves Kabul in a weak position to negotiate during the IntraAfghan Dialogue. That is particularly relevant as Kabul will soon have a reduced security sector umbrella from the Pentagon under the terms of the peace agreement. "Without U.S. support, Kabul will have to contend with an even wider power vacuum across the country while competing with the Taliban that controls more territory in Afghanistan than at any other time since their 2001 withdrawal from power"(Larson, 2020).This and other failures in comprehensive political preparation are reminiscent of the Geneva Accords and the Soviet withdrawal from Afghanistan three decades ago, which gave way to the fall of the Kabul government and the restoration of Taliban power soon afterwards. The consolidation of political power in Kabul will be extremely challenging, especially in the place of powerful illicit networks across Afghanistan as well as power structures organized locally and regionally. The way in which the Afghan Government involves these actors in consolidating its authority will have a major impact on the political development of Afghanistan for decades to come.

The Taliban's relationship with Pakistan could change considerably in the event of a comprehensive political settlement between the Taliban and Kabul. If the Taliban becomes "a legitimate political unit in the Afghan government and no longer needs to exist as an illicit group in refuge, then it may provide Islamabad with a good opportunity to push harder to eradicate the group from the Federally-Administered Tribal Areas (FATA), Khyber-Pakhtunkhwa province, and other areas of the country where they are allegedly operating"(Jamal, March 06, 2020).This would certainly be a daunting and contentious undertaking in Pakistan, but such a scenario could help Islamabad catalyze the international development assistance that Prime Minister Imran Khan has sought, rebrand his international profile, and that neighboring countries' perception of the danger to nonstate groups tacitly permitted to operate outside Pakistan. Nevertheless, this depends on a settlement in Kabul which is anti-India enough to appease Islamabad(Jamal, 2020, March 06).

\section{Challenges to the Peace Process}

The long-standing refusal by the Taliban to recognize Kabul as Afghanistan's legitimate government does not bode well for effectively establishing a significantly substantive intra-Afghan dialogue. Additionally, the fragmentation of the Taliban weakens the credibility of any promises made by the organization in a peace deal, as its political leadership may lack the coercive capacity to enforce a ceasefire between its splintering and peripheral groups. Kabul will also not want to negotiate under threat from the Taliban, although attacks against the government have already been resumed by the group."Can the Taliban become a political party with seats in the legislature and a quota of power-sharing within bureaucratic / unelected divisions of the state, should the two come to a political settlement? Or will they be granted an autonomous Afghan region to rule with a separate set of political structures that govern their relationship with the Kabul political centre? Power-sharing agreements legitimize differences among groups in government by forcibly giving political weight and relevance to their identities, as continues to be the case in Lebanon. It would be dangerous to build such an agreement in Afghanistan, and would require intense caution to avoid political gridlock"(Bonesh, 2020, March 31).How the United States will accurately track and implement adherence to such a policy is difficult to imagine, considering that Taliban intelligence would almost certainly not exchange 
information with the Central Intelligence Agency of the United States.A significantly reduced US security contingent would also make it very difficult to track whether the Taliban was hosting Al-Qaeda and the Islamic State, or tacitly supporting it. The capacity of the Islamic State, al-Qaeda and the Taliban to operate concurrently in Afghanistan will pose a formidable challenge to Kabul's authority and consolidation of democracy. Additionally, given the increasing unpopularity of the invasion and the enormous amount spent by Washington to maintain its war effort, "it is extremely unlikely that the United States would re-enter Afghanistan militarily following a withdrawal. The Taliban may use this to their advantage and spread power by coercion, or take the opportunity to legitimize themselves as a political party, ban al-Qaeda and the Islamic State, and diminish the chances of US re-engagement more sustainably"(Thomas, 2020, May 1).

The total Afghan refugee population is around 2.5 million and constitutes the world's second-largest protracted refugee community. Will negotiation between the Taliban and Kabul provide any clauses for refugees, most of them are forced to live in Pakistan and Iran as third class citizens? Rebuilding the Afghan economy would definitely entail an influx of labor and expertise, "but a general lack of economic opportunity in Afghanistan also contributes to the attractiveness of non-state actors and terrorist groups. If the government of Afghanistan (possibly in collaboration with the Taliban) cannot provide a decent livelihood, repatriating several million Afghan refugees would do nothing to help stabilize the country and bring people out of poverty"(Jamal, 2020, March 06).

The U.S.-Taliban peace deal signing saw a media frenzy over the eventual removal of U.S. and NATO troops, so what are the odds of it ever coming to fruition? It is uncertain what the full scope of the withdrawal would be - whether it is fully complete or something like the continuing involvement of the United States in Iraq. Perhaps the United States will retain on-the-ground air support and guidance to ensure that the terms of the agreement are met. In this situation, U.S. participation - should Kabul and the Taliban enter a power-sharing arrangement - would see Washington offer assistance to a security sector that involves the Taliban. That said, withdrawal from Afghanistan and potentially leading to a collapsed state scenario would seriously delegitimize the support for democracy in the United States and state-building programs worldwide. Each element of monitoring and assessment for this agreement will prove to be extremely challenging for any participant involved, state and non-state, and that will challenge significantly the execution of the ongoing provisions of the agreement, including the eventual withdrawal of international military forces(Bonesh, 2020, March 31).

\section{Findings}

Signing the "Agreement to Bring Peace to Afghanistan" is the outcome of a long and arduous process to end this long and devastating war. There are however a number of snags that can prevent full implementation of the agreement. The Afghan Government was not a negotiating party, for one. Afghan President Ashraf Ghani does not support many of the agreement's sections and has objected to taking the next steps needed to move the peace process forward.

An additional problem is that the last presidential election in Afghanistan was contested, resulting in a split and dysfunctional government in Kabul. No one is in charge 
in Kabul with two competing candidates declaring themselves winners. As the next stage of the peace process is for negotiations between the Taliban and the Afghan government to take place, a divided and fragmented government in Kabul is making the next move difficult.

The Taliban itself is a divided house, with the agreement being signed by its political leaders, but the field commanders might not be on board. These commanders are younger and tested for battle, and fought in hard and remote parts of the country. They are the core of the Taliban and many have their own agendas that might be at odds with the peace deal.

Yet given these possible concerns, America's main objective was to withdraw its troops from Afghanistan. That objective has been achieved; American troops are leaving Afghanistan now. President Trump has campaigned to get the American troops or Afghanistan out and he needs to fulfill that promise with another election coming up. What's happening to Afghanistan is less significant.

But what's going to happen next is still a question. Although the withdrawal of American troops from Afghanistan was temporarily halted on March 18th 2020 because of the coronavirus outbreak American forces have already started to leave the region. Some in the U.S. question the terms of the agreement, and even call it a surrender document. With a fragile regime in Kabul and with the U.S. withdrawing its supporting troops, some would say supporting the Kabul government, others would be afraid that the Taliban would wait until the U.S. troops left and then overrun Kabul, as they did in 1995. If this happens it will be for naught the 20 years of war and the loss of almost 2,500 American lives. It just starts to look like Vietnam in 1975.

\section{Conclusion}

The US-Taliban agreement marks an essential milestone in the contemporary history of war-torn Afghanistan. It remains to be seen whether this will prove to be a positive turning point, i.e. leading to a de-escalation of conflict, or a negative one heralding the beginning of a new escalating phase of violence in the decades-old civil war in Afghanistan. The experience of Afghanistan over the past four decades, the brutal and bloody record of the Taliban, America's own history of washing its hands off Afghanistan once its limited goals have been met, and the sheer complexity of the Afghan conflict indicate that the Peace-Building Agreement for Afghanistan may not bring peace to the war-ravaged country. At best, the Doha deal could provide a pause before the key actors in the conflict return to the battlefield.

\section{Recommendations}

Peace is a process, not a short-term plan. It is about building trust between people, between the population and their authorities. The US-Taliban peace talks have been troubled since the beginning because they ousted a key player in the Afghan conflict i.e., the democratically elected Afghan government. Washington seems split over the peace accord, with widespread skepticism as to whether the talks will yield the desired outcome. 
Similarly, groups within the Taliban ranks have contributed to the uncertainty between the international community and the government in Afghanistan. Even if the US and the Afghan government have to make a deal with the Taliban, if they're not on the same page with their different factions, it won't bring lasting peace because when one side felt ignored and overlooked, they opted to manipulate the peace talks that led to cancellation of peace talks. It occurred the day before the Taliban were set to meet President Trump in Camp David.

At this critical juncture, the success of the Afghan peace talks now is contingent exclusively on the formation of an inclusive team of negotiators who represent all sections of Afghanistan and protect the republic.

On the national front, the Afghan government should build internal consensus by negotiating with the Afghan political opposition and including their representatives in the negotiating team.

Similarly, this phase should be perceived by the Afghan opposition headed by former President Hamid Karzai as a path to reconciliation but not as a chance to return to power.

The US have to accept the ground realities of peace talk and have to be remain intact with the terms which they have made during the peace accord.As part of confidencebuilding steps, the US should release Taliban leaders as their last bargaining chip to demonstrate that they are committed to the perpetual peace.

The Taliban must reciprocate in the similar way by, demonstrating solidarity, flexibility and display mutual respect by changing their aggressive tone and approach to the Afghan Government. Taliban need to realize that the path to peace ultimately goes through Kabul, no matter what door they knock at. 


\section{References}

Ahmadzai, A. A. (2020). Hasty peace deal. Istanbul: TRT World Opinion.

Allen, J. R. (March 5, 2020). The US-Taliban peace deal: A road to nowhere. Washington D.C: The Brookings Institution.

Bonesh, S. A. (2020, March 31). Challenges of the peace process in Afghanistan. Hong Kong: Asia Times.

Commission, I. E. (2020). Afghan election result. Afghanistan: Independent Election Commission.

Datta, S. (2019, September 16). US-Taliban peace talks 'were doomed to fail'. New Delhi: Asia Times.

Gallagher, A. (2020, February 20,). U.S.-Taliban Deal is a "Massive Opportunity," Says U.S. Negotiator. Washington D.C: Analysis and Commentary.

Jamal, U. (2020, March 06). What Has Pakistan Gained From the US-Taliban Peace Deal? Lahore: The Diplomat.

Larson, A. (2020). Processing peace. London: Conciliation Resources.

Ramachandran, S. (2020). What Will the U.S.-Taliban Peace Agreement Bring for Afghanistan? Washington D.C: CACI Analyst.

Rogin, J. (2020, April 18). Big questions surround the coming U.S.-Taliban peace deal. Washington D.c: Global Opinion.

Thomas, C. (2020, May 1). Afghanistan: Background and U.S. Policy:. :C.D ,Washington .Research Service Congressional 